\title{
Portrayal of InVADERS AND CONQUERORS OF InDian SubContinENT: ANALYSis OF History Textbooks Studied in Pakistani Schools
}

\author{
Ashar Johnson Khokhar ${ }^{\mathrm{a}}$ \\ Forman Christian College
}

\begin{abstract}
The textbooks are believed to be containing true and authentic historical narratives and it also remained the sole tool employed by a state to impart a certain notion of its identity. The qualitative perspective best suited this research, and within it, the qualitative content analysis method was chosen to analyze the content of textbooks. This study analyzed history textbooks of classes six to eight published by the three state textbook authorities in Pakistan. The focus of the textbook analysis was to identify discourse strategies used to construct, reinforce and strengthen a certain notion of pupils' identity. The study revealed the use of representation, unification, avoidance, and trivialization strategies as the textbook writers created images of invaders, conquerors and rulers of the Indian subcontinent and the impact on Indian people and society. This study suggests that history textbooks should present history with multiple interpretations using multiple sources to construct a historical narrative.
\end{abstract}

Keywords: Muslim invaders, Muslim rulers, Indian subcontinent, Identity, History textbooks, Hindu rulers, Hindu religion, Hindu society

\section{Introduction}

Textbooks are studied for quite some time now with varying purposes, such as cultural and social aspects of textbooks; promotion of harmony and understanding among different ethnic and religious groups; identifying stereotypes, prejudices, and misrepresentation (intentional or unintentional); women and their representation in textbooks; social, cultural and religious influence on textbooks; the process of textbook design and publication; politics of textbook writing and approval; politics of textbook content, its selection and writing, teachers' classroom pedagogical practices; and textbooks didactical quality (van Wiele, 2008). The textbooks are also analyzed to develop inclusive society (multiculturalism, peace education) especially through history, geography, civics, and language textbooks as democracy, intercultural and international awareness, and human rights are relevant to these textbooks.

The History (including Social Studies), English and Urdu textbooks are inextricably entwined with each other in Pakistan because all these textbooks contain historical narratives. The History and Social Studies encompass pre, and post-partition history while the English and Urdu textbooks focus on the post-partition history of Pakistan. This study is delimited to Social Studies and History textbooks of classes 4 to 8 . The purpose of this study is to identify how different invaders were imagined and presented to pupils in the historical narrative in textbooks analyzed here. This study will also reveal how writers silenced history as they choose not to present a particular era in the textbooks to pupils. This paper will also reflect, briefly though, on the impact of the images of Muslim invaders and Muslim rulers of the Indian subcontinent presented in the textbooks.

a Correspondence can be directed to: asharkhokhar@fccollege.edu.pk 


\section{Literature Review}

\section{History Textbooks, Religion and Identity}

Identity and affinity to a certain history are formed through textual resources, especially national history narrative found in history textbooks. These narratives become "transparent windows on reality" (Bruner, 2002, p 6) to pupils where they view the past through these narratives. It is suggested that "identities by themselves do not exist; they are constructed by identity narratives" (Martin 1995, p. 15). Wodak, De Cillia, Reisigl, and Liebhart (2009) pronounce that there is "no such thing as one national identity" because "different identities are discursively constructed according to the audience, setting, topic and substantive content" (p. 4). The narrative also "impose a structure" of how the past should be imagined "a compelling reality on what we experience, even a philosophical stance" (Propp, 1968, p. 89). It is argued that a narrative is a narrator's perspective, but it also requires the narrator to synchronize itself with the narrative, which manifests itself through its writing style and the language (words and phrases) used in these narratives. The narratives are a site of shaping and reshaping national identity and identities which are conflicting and varied within a nation and a state, thus negating the idea of a singular identity of a citizen and of a state because of various groups promoting sets of identity narratives (Ozkirimli, 2000, 2005).

The debate on identity could not be completed without discussing religion and its impact on identity construction. The debates in the West about Western identity and in the Muslim world about Muslim identity were reshaping the national discourses on identity as religion became a core point of discussion shaping national identity discourses (Berggren, 2009; Kurth, 2007; Myhill, 2006). The new meanings of identity with religion as a core component of the identity construct and search for a new meaning of identity in a diverse society (ethnic, religious and linguistic) became the focus of many debates and studies in both the West and the Muslim world. The European and American identities and Christian values became synonymous, while Muslim identity was coupled with Islam and its values (Berger \& Lorenz, 2008; Berggren, 2009). This debate also contributed in the history writing exercises of different countries and some history textbooks gave space to minorities (migrant groups in the Western societies) and in some, it still continued to be debated by the states and their textbook regimes and minorities struggled to get acknowledged in the national discourses, especially in Muslim majority countries.

The founding father, Muhammad Ali Jinnah recognized in his very first speech to the members of the first constituent assembly of the newly created state of Pakistan that there were "majority and minority communities - the Hindu community and the Muslim community" (Government of Pakistan, 1947). He highlighted the differences within Muslims (Shias, Sunnis, Pathans, Punjabis, Balochis) and Hinuds (Brahmins, Vashnavas, Khatris, also Bengalese, Madrasis) and suggested that these differences would vanish under state's narrative of equality, justice and fairness. Jinnah's address continued to be discussed by both sides of the divide on Pakistani identity as they addressed the roots of Pakistani identity and Jinnah's vision of Pakistani identity and both sides found references to support their argument, be it the conservative or liberal groups.

A few recent studies (Ahmed, 2017; Durrani, Dunne, Fincham, \& Crossouard, 2017; Kalin \& Siddiqui, 2017; Shah \& Ishaque, 2017) noted that religion and identity remained integral to Pakistan's national identity narrative and continue to embed it in Pakistan's national security narrative. The textbooks (especially Social Studies, History, Geography, English and Urdu) continued to be the sole source of communication of the national historical, political, cultural, and religious narratives to pupils and reinforce and reconnect the national narrative with Pakistan's security. The Government of Pakistan (GoP) focused on using religion as a tool to promote national integration and assimilation of different ethnic groups presuming that the assimilation model would make these groups abandon their socio-political and cultural loyalties and make these differences irrelevant. The differences between and among ethnic, religious, social and cultural groups would diminish because the government would use its known and unknown means and devices to enforce the differentialist 
model, which was to negate the pluralist Pakistan, imagined by Jinnah in his first address to the first constituent assembly of independent Pakistan pronounced

You are free; you are free to go to your temples, you are free to go to your mosques or to any other places of worship in this State of Pakistan. You may belong to any religion or caste or creed - that has nothing to do with the business of the State (GoP, 1947)

\section{History Textbook Revision in South East and South Asia}

The history textbook revisions were a product of conflict between groups within a country and concerns shown by other countries. The textbook revision exercises in South East Asia and South Asia are examples of this. The studies about history textbooks in Japan, China and South Korea generated heated exchanges between these countries where China and Korea used history card, "a tool available for shaming, pressuring, and gaining leverage on the Japanese government" (2008, p. 110) observed Schneider. The changes in the Japanese history textbooks perspective became a political hotspot between the ruling party and the conservative politicians and groups. The changes made in Japanese history textbooks turned out to be political warfare between these countries (Biontino, 2018; Duus, 2017). The history textbooks in South Asia, especially Bangladesh, India and Pakistan, went through various revision exercises though these countries shared historical past, its rulers, culture, arts, monuments and literature. Though the majority of the Indian subcontinent (under British rule) belonged to the Hindu religion with Muslims, the second minority group consists of many other small ethnic and religious minority groups such as Sikhs, Christians, Zoroastrians, Buddhists and many small indigenous religious groups. The history textbook revision exercises were influenced by religion as it became a key pillar to construct the national political, cultural and historical narrative around it. The Indian history textbooks removed references to Muslim rulers and added more references of Hindu rulers in their history textbook (Dalrymple, 2005; Emerson \& Levi, 2020; Habib, Jaiswal, \& Aditya, 2003; Rahman, Hamzah, Meerah, \& Rahman, 2010; Rosser, 2003; Sen, 2012; Sharma, 2020). These studies also revealed how Bangladesh and India were reinventing their history and reinterpreting different historical events shared by these countries to suit their narrational, political, cultural and religious narratives. The rewritten historical narrative created 'us and 'them' where parts of history were given more space and presented in a positive way (positive representation strategy) while some parts of history were either trivialized (given little space) or avoided (given no space) in history textbooks, deemed unworthy and unacceptable by the state because of its being incongruous with its political, cultural and historical narrative.

\section{History Textbook Revision in Pakistan}

History textbooks in Pakistan have gone through many phases of revisions, and two forces, wars with India (1948, 1965 and 1971), and the Zia-ul-Haq's Islamizing education and curriculum policy continue to influence textbooks. These forces shaped not only the history curriculum but other subjects, such as English, Urdu, Ethics, Islamic Education, Sciences, and Mathematics. The earlier studies highlighted that the ruling elite focused more on state-building and paid little attention to nation-building, and this continues to be the focus of history textbooks (Durrani, 2013; Durrani et al., 2017; GoP, 2009; Joshi, 2010; Qasmi, 2019). The defeat of the Pakistan Army in the Eastern wing of Pakistan (that resulted in the emergence of East Pakistan as a separate country, named Bangladesh), reignited the debate on state-building. This time around, the state decided to use Islam as the tool to be employed to construct a certain notion of Pakistani identity, an imagined identity, derived and rooted in the Muslim invaders and Muslim rule in the Indian subcontinent. The conflict with India and wars with India ware used to reinforce this identity.

The second phase of curriculum revision (Zia-ul-Haq's Islamizing education) used Islam as the only force that would shape the curriculum and textbook content, and this revision resulted in changes 
that were well documented in different studies. Since this study was focused on history textbooks, only historical narrative and history textbooks would be discussed here. The studies (Hoodbhoy \& Nayyar, 1985; Kurin, 1985; Zaidi, 2011) highlighted the writing of the history curriculum under Islamic influence and aimed to promote a particular version of Islam, its history and impact on the world and the Indian subcontinent. The historical narrative found space in other textbooks (English and Urdu, the two core subjects studied by pupils from grade 1 to grade 12) showed the emphasis on a certain notion of identity, which these scholars considered 'distorted' because it was founded on a distorted version of history.

\section{Education Policy and History Textbooks}

Pakistan, in its 73 years as an independent country, had seen eight education policies and numerous education commissions. The focus of each of these policies and commissions was to produce 'good citizen' (read patriotic citizens) and the latest education policy adopted in 2009 was not different from the previous ones. However, the 2009 education policy was formulated under a moderate regime which was not the case with the education policies that came out in $80 \mathrm{~s}$ and $90 \mathrm{~s}$. The curriculum content (textbooks) in 60s and 70s were written to promote conservative Islam but the 80 s and 90s saw it shifting towards fundamentalist Islam. General Zia-ul-Haq's regime brought about changes in curriculum policy to appeal to a vast religious constituency, Sunni Muslims, and to seek the political legitimacy of his military rule (Lall, 2008, 2012).

General Musharaf's military regime tried to undo the Islamizing curriculum policy but failed (Muhammad \& Brett, 2017) because the ruling elite, made up of Sunni bureaucracy, Sunni military leadership and Sunni business and trading classes opposed it. This document was prepared by the liberal civil society groups with minimum interference from the powerful bureaucracy. The document presented Pakistan as a pluralistic society and vowed to promote a globalized pluralistic worldview in its curriculum policy. This document was opposed by the religious groups and members of the National Assembly and the Senate refused to adopt it unless modified as per their demands. The policy document was sent to the bureaucracy that ensured that curriculum policy did not shift its focus from Sunni version of Islam and the antagonistic approach of curriculum towards India (Muhammad, 2015). The adoption of the modified 2009 education policy showed that it was difficult to shift the focus of Sunnified education and curriculum policy. It was predicted (Ahmad, 2008; Ali \& Rehman, 2001) that the Zia regime's Islamization of the education and curriculum would be difficult to reverse because Pakistan became dependent on Islam and Islamic nationalism as the sole source of its identity and of it becoming an obstacle in constructing a globalized identity of the people of Pakistan.

The latest education policy stated the purpose of education as "to play a fundamental role in the preservation of the ideals, which lead to the creation of Pakistan and strengthen the concept of the basic ideology within the Islamic ethos" (GoP, 2009, p. 17). The education policies considered the Objective Resolution as the primary document and emphasized on presenting and promoting the distinct identity of the people of Pakistan to pupils, which was different from the people of India. The differences between the Pakistani and Indian identity were of religion; the former was rooted in Islam while the latter was embedded in the Hindu religion. The textbook writers highlighted these differences, especially the religious difference, and these descriptions created ' $u s^{\prime}$ and 'them' not only in the Indian subcontinent but elsewhere as well (Mohammad-Arif, 2007; Naseem, 2005; Naseem, Ghosh, McGill, \& Mcdonald, 2010; Qasmi, 2019; Saigol, 2003, 2005; Zaidi, 2011), The differences between Muslims (us) and non-Muslims (them) were highlighted and presented to the pupils by eulogizing the former and presenting the latter as the opposite of the former.

Two recent researches were important because they were related to the history writing project of Pakistan. Chughtai's (2015) doctoral thesis analyzed how the textbook regime in Pakistan produced history textbooks while Qasmi (2019) in his research article, analyzed how Pakistan's history writing project that started in 1947 shaped the pre-partition and post-partition historical narrative. 
He concluded that the individuals and institutions (government backed) involved in history writing project severed the historical, cultural and linguistic ties "with the region that had nurtured the idea in the first place" (p. 38). The territorial, cultural and linguistic links with the Indian subcontinent were perceived and presented as a threat to the Pakistan and its population (Muslims). The history writing exercise trivialized the Hindu ruled subcontinent, its people, their religion, culture and landscape by giving no space to Hindu rulers and their social, cultural, and political contributions to the Indian subcontinent's society. Chughtai (2015) concluded in her thesis that though Pakistan's foundational ideology became rooted in Islam and its fundamentals, yet Pakistan's ruling elite, through its different apparatus including textbook regime failed to create a "demand for a politically extremist religious nationalist state" (p. 200). She concluded that it showed that the majority of the people of Pakistan were not inclined to make Pakistan an Islamic political extremist society and country.

\section{Representation (us and them) in Pakistani Textbooks}

The construction of contested historical narrative in Pakistan was drawn from "the historical themes, the periodisation, the geographical imaginings, and the heroes and villains of this historiography were drawn from the pre-partition discourse of Muslim nationalist historiography" (Bajwa, 2009, p. 5). The textbooks' narratives chose heroes, villains, and events to be glorified and remembered, and those that should never be mentioned and made part of Pakistan's historical narrative. The textbook writers found a master narrative (Thijs, 2008; Wertsch, 2008) imposing a certain shape on the identity narrative written in textbooks whereby 'Islam' became a common link to understand and construct past. This construction of the past established the nation-state 'Pakistan' and its demand in the earlier history of Muslims in the Indian subcontinent and Islam's dominance in the Middle East, North Africa, and Southwestern Europe. The narrative was rooted in religion, that is Islam, and this was also used to create ' $u$ ' and 'them'. The Indian subcontinent was viewed in terms of Hindus and Muslims continuously fighting for land and control over its resources for centuries. The latter won most of the wars and brought about positive changes that otherwise, would not be possible to implement; while the former being inferior not only in terms of military prowess but also in their social, cultural and religious outlook of society.

The representation of Hindus as 'them' in Pakistani textbooks could be traced back to the earlier years of Pakistani textbooks (Aziz, 1993). He identified many fallacies and incorrect information in textbooks and his work, considered as the benchmark and trendsetter in such studies in Pakistan as many academics (Durrani, 2013; Durrani \& Dunne, 2010; Durrani et al., 2017; Fazila-Yacoobali, 1999; Giunchi, 2007; Saigol, 2003, 2005; Yaqian, 2011; Zakaria, 2018) followed Aziz's work and continued working in this area. The idea of non-Muslims (Hindus in particular) being the only enemy of Muslims in the Indian subcontinent was given significant space in textbooks, and all platform, political, social, cultural, and religious were used cement the differences between Muslims and non-Muslims. The concept of Hindus as the enemies of Muslims and Islam was extended to Indian National Congress which was presented as a project envisioned by the Hindus, and the British, the enemies of Muslims, to weaken Islam and Muslims in the Indian subcontinent. The Hindus and British worked together to weaken the Muslim rule and Islam as they confiscated not only powers from Muslims but also their resources, their land, their livelihood and businesses and redistributed it amongst non-Muslims.

\section{Research Methodology}

This study analyzed history textbook content using a qualitative approach due to its ability to unravel the history textbooks content and understand how the Indian subcontinent and its history were imagined and presented to pupils. This approach provided "an in-depth, intricate and detailed understanding of meanings, actions, non-observable as well as observable phenomena, attitudes, intentions and behaviours" (Gonzalez, Brown, \& Slate, 2008, p. 3) presented to pupils through the actions of different invaders, Muslims and non-Muslims, found in narratives. 
This study made use of a qualitative content analysis method to analyze date (textbook content). It was becoming popular amongst academics and researchers working in the arts, humanities, and social sciences fields. The rapid advancement in science and technology and computer applications also contributed to make research plans, organize, and execute research projects in a systematic fashion, especially the analysis of complex and huge data (Neuendorf, 2017). Content analysis was explained as "systematic, objective" whereby researchers through "careful examination" of the language used in textbooks "predicted relationship among variables measured in the content analysis" (Neuendorf, 2017, p. 72). The data analyzed in this study was complex because of the nature of the data, content from history textbooks due to the naturalistic settings of these textbooks. The categories (see Figure 1) were thematically derived from the textbook content after the careful reading of textbooks.

Figure 1: Analytical framework
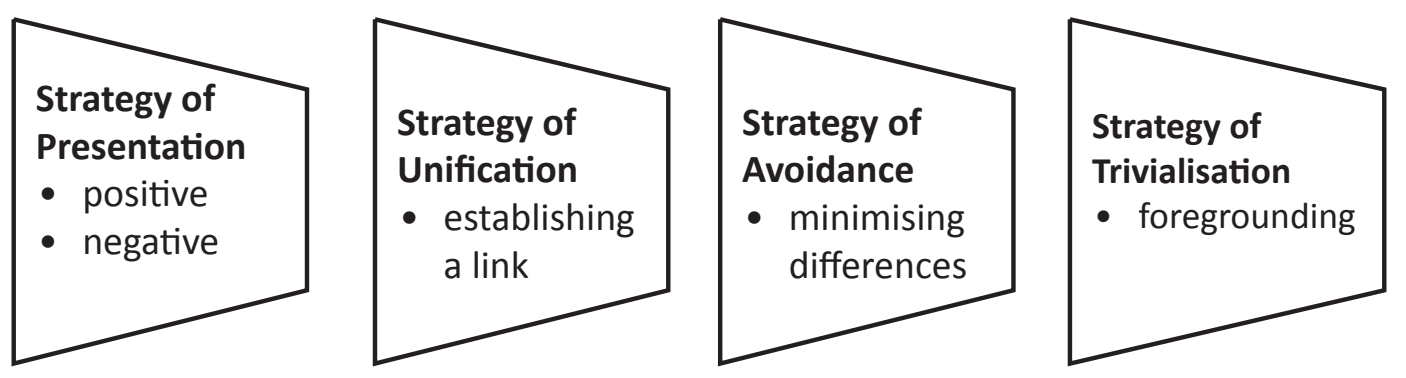

This study analyzed nine history textbooks published by three government created textbook boards which are Punjab Curriculum and Textbook Board (PCTB), Sindh Textbook Board (STB) and Khyber Pakhtunkhwa Textbook Board (KPKTB). The first reading of the textbooks helped in creating a list of invaders found in history textbooks, while the second reading was used to identify words and phrases used to describe them. A profile of each invader was created using the words and phrases used in the textbooks. Some of the profiles were short, and some of them were long, and this showed that some of the invaders and conquerors were given little space, and some were given more space in textbooks, highlighting the value and importance of different Muslim invaders and Muslim rulers of the Indian subcontinent in Pakistan's historical narrative.

This study used an analytical framework (see Figure 1) borrowed from Wodak et al. (2009) and Klerides (2008). These two studies analyzed at texts (textbook and interviews) and identified strategies used (by textbook writers and citizens) to construct, reconstruct, deconstruct, and strengthen their identity. The strategy employed mostly by textbook writers and given considerable space in the textbook was the presentation of invaders, which communicated both positive and negative images (representations) to pupils. The second strategy found a common link connecting all the images, while the third strategy revealed the difference or differences between and amongst different images and representations. The fourth strategy used by writers was of foregrounding history.

\section{Findings and Discussion}

Indus Valley Civilization, Aryans and Muslim

\section{Strategy of Representation}

The Indus Valley Civilization was the first image of South Asia, and writers juxtaposed two groups, Muslims and non-Muslims, against each other and asked pupils to compare these two groups (see Table 1). They employed the positive representation strategy for the former and the negative 
representation for the latter. They also compared religions (Islam Hinduism and Buddhism) and presented Buddhism as a positive influence on society and portrayed Hinduism as a negative influence (see Table 2) because of its practices. There were two opposite sets of words, the positive representation, (peaceful, kind, generous, welcoming, a developed community, developed city) and the negative representation (cruel, unsympathetic, no civic sense, fighting and quarreling all the time, taking advantage of others' generosity and kindness). The artefacts displayed in museums in Pakistan also reflected the glory of Gandhara and Indus Valley Civilizations (Buddhist). The Museums had nothing that would be reminiscent of Aryan civilization and Hindu rule and reflective of their achievement (Amstutz, 2019). It showed that writers wanted pupils to connect themselves to Gandhara and Indus valley civilizations and not with the Aryan civilization because what was attributed to the former was also attributed to Muslims and Islam.

\section{Table 1: Profiles of Indus Valley Civilization and Aryans}

\begin{tabular}{|c|c|}
\hline Indus Valley Civilization & Aryans \\
\hline $\begin{array}{l}\text { a religious state, followers of Buddhism, peaceful, } \\
\text { farmers and agriculture-related industry, developed } \\
\text { complex system of government, the state collected } \\
\text { taxes, build grain stores to store grain, build cities with } \\
\text { all amenities (sewage system, roads, public meeting } \\
\text { and recreation places), public schools and universities, } \\
\text { rich culture, knowledge flourished, generous, tolerant } \\
\text { and welcoming, a constructive force, }\end{array}$ & $\begin{array}{l}\text { once refugees in the land, hungry and looking for } \\
\text { shelter and food, cruel, ungrateful, unsympathetic, } \\
\text { no civic sense, always fighting and quarreling with } \\
\text { each other, physically strong, forced out local people } \\
\text { from their land and captured their area, made } \\
\text { them work as slaves, forced their religion (an early } \\
\text { form of Hinduism, primarily focusing on separating } \\
\text { society into groups, that is, the caste system in } \\
\text { modern Hinduism), excluded a large population } \\
\text { (untouchables) from the community life, fond of } \\
\text { dance and music, a destructive force }\end{array}$ \\
\hline
\end{tabular}

References: KPKTB, 2017a; PCTB, 2017a; and STB, 2017a

Table 2: Differences between Buddhism and Hinduism

\begin{tabular}{lll}
\hline Hinduism & \multicolumn{2}{l}{ Buddhism } \\
\hline - & Belief in caste system & No caste system \\
- & Brahmans had an important role & Brahmans were criticized \\
- Spending lavishly on religious rituals and customs & $-\quad$ No spending on rituals or customs \\
- Vedic books are sacred. & $-\quad$ Vedic books are not accepted \\
- Some sort of belief in God & - No belief in God \\
- $\quad$ Animals sacrifices were offered & - No animals were sacrificed \\
- No central prophet in Hinduism & $-\quad$ Buddha was the central Prophet \\
\hline
\end{tabular}

Reference: KPKTB, 2017a, p. 21

The next list of images was of invaders from present-day Afghanistan, Middle East, Central Asia, and Europe. The writers compared the Muslims invaders with the local (Hindu) rulers and presented the former using the positive representation strategy while the latter was described using the negative representation strategy, just the opposite of the former (see Table 3). The scholars (Avari, 2007, 2013; Bose \& Jalal, 2017) identified "Aryans, Greeks, Scythians, Parthians, Shakas and Huns before the eighth century, as well as Arabs, Persians, Turks, Afghans and Mongols between the eighth and the twelfth centuries" (Bose \& Jalal, 2017, p. 22) invading the Indian subcontinent. The analysis of textbooks revealed that textbook writers chose only a few of them and made them part of history textbooks such as Aryans, Greeks, Muslims from Persia, and Central Asia. 
Table 3: Representation of Muslim Rulers against the Local rulers (Hindu)

\begin{tabular}{ll}
\hline Muslim Rulers & Rajputs (Hindu Rulers) \\
\hline brave, intelligent, lenient, generous, kind, gave money & scheming, cunning, greedy, against Muslims and \\
and land to build temples, opened schools (Islamic), & Islam, no contribution in Sciences, literature, art, \\
build mosques, welcome traders, industrialists, united by religion \\
developed infrastructure, improved agriculture, art, \\
and literature flourished, treated local population \\
(Hindu) with respect, gave them land and money \\
to build temples, did not interfere in their religious \\
customs and rites
\end{tabular}

References: KPKTB, 2017a, 2017b, 2017c; PCTB, 2017a, 2017b, 2017c; STB, 2017a, 2017b, 2017c

The textbook writers presented all Muslim invaders and rulers were connected through religion, Islam, and this connection was aimed at creating a just and fair society in the Indian subcontinent. To do it, the writers created two categories, (a) person and (b) ruler. The first category described the personal traits, and the second category presented the attributes as a ruler. The majority of the Muslim invaders and rulers shared personal qualities such as god-fearing, religious person, pious, observant of religious practices, justice-loving, kind, generous, and sympathetic. Though there were a few Muslim invaders and rulers (Ameer Taimur and Nadir Shah) who were presented as 'foreign invaders, attacked the Indian subcontinent because of its riches, plunder the land, took its looted wealth and went back to their lands.' Some Muslim invaders and rulers 'fell into merry-making (Sultan Mubarak Shah Khilji), and un-Islamic way of life (using alcohol, drugs)' after becoming the ruler and their lifestyles provided an opportunity to Hindu Rajas to become strong and attacked Muslim territories in the Indian subcontinent. The textbook writers used trivialization and foregrounding strategies when it came to Hindu rulers, their governance structure, and society under the Hindu ruler and Hindu religion's influence.

\section{Strategy of Unification}

The textbook writers used unification representation strategy by linking the Indus Valley Civilization and the Muslim invaders and rulers; both were presented as a positive influence due to their social, cultural, religious system while the latter was a destructive force because their religion (Hinduism) was divisive, cruel and unsympathetic. Though there existed a long gap between these two eras, the Muslim invaders and rulers were presented as the saviors of the Indian subcontinent's and its return to the glorious Indus Valley Civilization era, after a long Hindu occupation of the Indian subcontinent. The textbook writers unified the Muslim invaders and rulers of the Indian subcontinent with the rulers of Indus valley civilization, and they shared the same social, cultural, religious, political values.

\section{Strategy of Foregrounding}

One would also find the use of strategy 4 where images of the destruction of wars, expulsion, famine, and religious conversion were foregrounded, suggesting that nothing of these happened in the Indian subcontinent under the Muslim invaders and rulers, that is, the defeated army (Hindu) was not treated as an enemy army; they were no expulsion of Hindu rulers, Hindu aristocracy and Hindu population after those lands were conquered; there were no forced or incentivized religious conversions; the subcontinent became rich and prosperous, and there was no famine in the land. There are studies that have highlighted how the Muslim invaders and ruler used tax system and 
offered incentives (land and title) to encourage the conversion of people (rich and the poor, especially the lower caste Hindus) to Islam as was suggested in earlier studies on Indian history.

I encouraged my infidel subjects to embrace the religion of the Prophet, and I proclaimed that everyone who repeated the creed and became a Mussulman should be exempt from the jizya, or poll-tax imposed on non-believers. When this information came to the ears of the people at large, great numbers of Hindus presented themselves and were admitted to the honour of Islam. Thus they came forward day by day from every quarter, and, adopting the faith, were exonerated from the jizya and were favoured with presents and distinctions (Lane-Poole, 1906 as cited in Al-Sahli, 2013, p. 39)

The textbooks studied in this study started the South Asian region's history with the Indus valley civilization, describing the Aryan period briefly, and explaining in great detail the Muslim and the European and British invaders and rulers. The quick jump to Muslim invaders and rulers' history in the Indian subcontinent left a huge period uncounted in the history of the Indian subcontinent. The history was divided into four parts (i) Pre-historic era (until c. 2000 BC), this includes the Indus valley civilization); (2) Vedic and post-Vedic era (2000 BC to $300 \mathrm{BC}$ ), this includes the Aryan rule; (3) The era of the Great Empires (c. $300 \mathrm{BC}$ to c. AD 500), this includes Mauryan Empire, and (4) The feudal era( from c. AD 500 to c. AD 1200 and beyond) which includes the Muslim invaders and rulers from Arabian Peninsula (Arabs), Central Asia (Turks) and Europe (Avari, 2007). There were two interpretations of Aryan; the first presented them as barbarian invaders with no civic sense, greedy and quarrelsome; while the second interpretation described them as landless people, a wandering tribe. It was summarized as follows

There was no Aryan invasion, but there was a migration of an Indo-European speaking group of nomadic people from Iran and Afghanistan, who called themselves Arya, or the noble. The Indo-Aryan culture has developed uniquely within India herself over the last four millennia, but its origins lie in the fusion of values and heritages of the Arya and the indigenous peoples of India (Avari, 2007, p. xvii)

\section{Strategy of Avoidance}

The other strategy employed here was avoidance, that is, minimizing differences; though these two groups (Indus valley civilization and Muslim rulers) practiced different religions and have a different religious outlook, their religious differences were minimized in order to establish a political connection between these groups. The writers did not highlight the conditions of non-Muslins under Muslim rule and only presented to pupils the positive aspect of Muslim rule and Muslim rulers. The textbook writers presented Muslim rulers as generous and caring; they distributed land and gave money to Hindus to build temples and abolished and reduced jizya (Islamic tax) on poor non-Muslims. The textbook writers suggested to pupils that Hindus converted to Islam because of the generosity, kindness, tolerance and equality shown by Muslim invaders and rulers towards the weak segments of society. There were other versions of the history which were missing from the textbooks (Sarkar, 2009) suggesting the otherwise, that conversions were due to heavy jizya imposed on non-Muslims, incentives and rewards to those who converted to Islam and back the Muslim invaders and did not join Hindu kings.

\section{The European Invader}

The European invaders and rulers were presented as a positive (see Table 4) and a destructive force (see Table 5) but mostly the latter for the Muslims of the Indian subcontinent. 
Table 4: European Invaders' Profile (Negative Representation)

\begin{abstract}
robbers, exploited local population, attacked and robbed Indian vessels, made people captives, forced people to work for them, kept them in dirty labor camps, demanded undue privileges, bribed locals, martyred Muslims, confiscated properties of Muslims, expelled them from services, abolished Arabic and Sunsikrat, promoted the English language, promoted western education and science, destroyed local industry, unemployment and poverty increased, harsh laws for dissenting opinion, hated natives, afraid of Muslims, abusive and cruel, no jobs for Muslims all jobs for Hindus, imposed new taxes Muslims, Muslim educational and religious institutions mal-treated, closed Muslim institutions, discouraged Islamic laws, Christian preachers established missionary schools, preached their religion, Islam and Islamic education system targeted. Converted locals (low caste Hindus) to Christianity.
\end{abstract}

References: KPKTB, 2017a, 2017b, 2017c; PCTB, 2017a, 2017b, 2017c; STB, 2017a, 2017b, 2017c

\title{
Table 5: The Europeans Invaders' Profile (Positive Representation)
}

\begin{abstract}
Improved infrastructure and communication services, discouraged caste system, encouraged female education, prohibited Sati, allowed widows to remarry, prohibited killing of newborn babies or burying them alive, fixed marriageable ages of girls and boys, abolished dowry
\end{abstract}

References: KPKTB, 2017a, 2017b, 2017c; PCTB, 2017a, 2017b, 2017c; STB, 2017a, 2017b, 2017c

\section{Strategy of Representation}

The negative portrayal of Hindu religion continued as the (dowry, marrying girls at a very young age, women killing themselves with their husbands or staying single, female infanticide) as prohibition and discouragement of such practices was presented as the positive contribution of the European invaders and rulers. The negative presentation was similar to the Aryan's description, using force to intimidate people, making them slave due to their better-organized army and weapons, annihilating their (Muslim) language (replacing English with Urdu and Persian) and social, cultural and religious practices (through the establishment of educational institutes, and social services such as establishing hospitals and structured bureaucracy). The establishment of Missionary schools and the state support of such education and health institutes were considered a tool to convert the local population.

The textbook writers' representation of the contribution of Muslim and European invaders and rulers is dichotomous as the former was presented as a set of rulers who brought about positive changes and made a significant contribution in the social, cultural, political, economic and religious lives of the people of the Indian subcontinent while the latter was presented as a force of destruction not only for the land and its resources but also for its people, especially Muslims and people from lower social and economic segments of Indian society. The Muslim invaders and rulers chose the Indian subcontinent as their land and made it their home. In contrast, the European invaders and rulers' laws and policies brought about positive changes and prosperity for those at the top tier of society, Hindus, and destroy the multi-ethnic, multicultural and multi-religious aspects of the Indian subcontinent built by the Muslim invaders and rulers over their long rule.

\section{Conclusion}

The historical narrative of Muslim conquerors, on the one hand, made Muslim heroes as the savior and messiah who came to the Indian subcontinent only to defend themselves from the attacks of Hindu rulers. The narration of Mahmood Ghazali's invasion from Central Asia happened due to continuous incursions of Hindu rulers' in his kingdom and to overtake his kingdom. The seventeen invasions resulted in huge plunder of land, and all of the loot was taken back to his kingdom in Central Asia, which he used to build mosques, religious schools, support the teaching of Islam and to fortify and expand his Islamic kingdom in what is now Afghanistan. This narration of events belittled the resistance of the local rulers, and people and textbook writers presented these rulers 
cruel and because of their cruelty, the local population did not support the rulers in wars against the Muslim invaders and rulers from Central Asia and Persia. The textbook writers used the positive representation strategy to present Muslim rulers, including Ghaznavi, eulogizing their attacks and what they did in their kingdoms with all the loot they gathered from the rulers and people of the Indian subcontinent. The misery and the struggle of people after these attacks were not explained to pupils though the textbook writers ensured that pupils learn about the negative impact of European invasions and European rule in the Indian subcontinent on Muslims of the Indian subcontinent. The use of trivializing strategy by the textbook writers, on the one hand, ignored the struggles and miseries of non-Muslims caused by Muslim invaders and rulers. On the other hand, the misery and struggle of Muslims under European invaders and rulers was explained in detail to evoke hatred and dislike of the European invaders and rulers.

The winner in this battle of the construction of the historical narrative of Muslim invaders and rulers from Central Asia and Persia was the all-powerful hegemonic bureaucratic and ruling structure in Pakistan. The ruling elite (civil and military) continued to exploit textbooks to achieve their hegemonic design on the ordinary people of Pakistan by presenting to them the 'official historical knowledge' which lacked 'historical knowledge.' The history writing and rewriting exercises were undertaken since the independence of Pakistan by the bureaucracy and by the bureaucracy backed individuals and organizations as was discussed and highlighted by Qasmi (2019). He called it an exercise initiated right after Pakistan became an independent state and continued till today to construct a master narrative of pre and post-independent Pakistan and of the Indian subcontinent's history. The textbook writers used positive representation and unification strategies as they constructed a historical narrative of the subcontinent and linked the Muslim invaders and rulers and Muslim rulers with the group of Muslim landed elite who established All India Muslim League in 1906. It was established by the Muslim landed elite of the Indian subcontinent that emerged as the only representative party of Muslims in the 1945-46 elections. The leadership of the All India Muslim League was presented as the continuation of the Muslim rule in the subcontinent and presented the creation of Pakistan and Pakistan movement as a struggle against the Hindu rule. The emergence of Pakistan was constructed as the beginning of returning to the glorious era of Muslim rule in the subcontinent.

The master narrative of Pakistan's history trivialized the Hindu rulers, and the people of the Indian subcontinent, Hindus, their religion, culture, and values. The master narrative of Pakistan's history of the Indian subcontinent started with the arrival of the first Muslim ruler from the Arabian Peninsula, named Muhammad Bin Qasim, and his arrival was also portrayed as a result of local Hindu ruler's vicious treatment of Muslims in his kingdom. The textbook writers foregrounded the Indian subcontinent's history under Hindu rulers. The textbook writers created a clear distinction between the society and people living under Hindu and Muslim rulers. The Hindu population living under Hindu rulers portrayed as unhappy, suppressed under the unjust tax system to support the ruling elite while the Muslim rulers broke all those chains and made them feel safe. The textbook writers used the concept of caste and satti (burning of wife on her husband's pyre) in Hindu religion as the evils of Hindu religion, which made Hindu religion the most disliked by the local population. The Muslim conquerors and rulers transformed the Indian subcontinent and they shaped it according to the Islamic teachings of equality, justice, and fair treatment of all, men and women, irrespective of gender and social status, opposite to caste system in Hindu religion.

The history textbook mirrored what was conceived in the education policy, Pakistan a nationstate and Islam gave it a unique character, an ideological country. The Pakistani historians backed by the bureaucracy conceived and presented Pakistan as a nation-state, a monolithic group of Muslims and where national integration project could only be materialized when Islam would be presented as a unifying force and India as an enemy country (Jaffrelot, 2002; Qasmi, 2019). The education and curriculum policies portrayed Pakistan as the only country in the world founded on the ideology that Muslims were different from other religious groups (read Hindus) and they should have a different country to practice their religion. This was translated into history curriculum and textbooks whereby 
Islam became a historicized force in history curriculum that would unite Muslims in Pakistan against its enemies (India and non-Muslims). The textbook regime in Pakistan tried to create harmony in the ethnically, linguistically and religiously diverse Pakistan by trivializing the differences between different Muslim groups (Islamic sects). Shafqat (2009) observed that history textbooks presented Islam as the "sole reason for the creation of Pakistan" and the founding fathers promised it as a land to preserve "Islam' and not simply 'Muslims of undivided India' as opposed to Hindus; they prefer Islamic belief over the group as the primary source of identity" (p. 2).

Religion guided and shaped the history writing exercise in South Asia in particular because India and Pakistan both continued to present the other's religion and rulers from other's faith as the enemy. Pakistan's portrayal of Aryans and Hindu nobility and rulers during Muslim rule in the subcontinent was the opposite of how India viewed and presented it to its pupils in its history textbooks. The subcontinent's history remained shrouded in mystery, and an Indian historian noted "it is a well-known fact that with the single exception of Rdjatarangini (History of Kashmir), there is no historical text in Sanskrit dealing with the whole or even parts of India" (Majumdar (1951) as cited in Witzel, 1990, p. 1). This claim was made in the voluminous Oxford History of Historical Writing (Volume 1 and Volume 2) in chapters on Indian history and history writing traditions (Ali, 2012; Thapar, 2011). The ancient history of the subcontinent continued to be written using Vedic text (religious texts of Hindu religion) as the sources of events, its chronology which may not have any evidence of its occurrence and this frustrated many early visitors to the Indian subcontinent such as Alburani who struggled to understand and comprehend the chronological order of subcontinent's history. Thapar (2011) suggested an explanation of this. He argued that time in ancient India was understood as "four yugas (cycles or ages) is often viewed as cosmological time" and "Indian texts suggest a heterogeneous time calculation. Even in the span of four yugas, the present is not a repetition of the past, since each age differs from the previous one" (p. 555).

The historical consciousness after the partition of the Indian subcontinent and the "scrutiny of the nationalist historiography became a significant task" for both the newly created countries and its ruling parties. The researchers explained the differences between Indian and the European understanding of history where the former was founded in "oral traditions, myths, and folktales" and the native historians "argued for a different and older relationship with the past" where "investigation of the Indian past was combined with a search for Indian frameworks of interpretation in postindependence historiography" (Mukherjee, 2011, p. 515); while the latter looked at history in the chronological pattern which "emerged from the Enlightenment, with an emphasis on sequential narrative and chronology, and a focus on political authority" (Thapar, 2011, p. 553). The Indian history project conceived and initiated after it becoming an independent country was viewed as "mostly hagiographic in kind, celebrating India's 'glorious past' and 'heroic struggles' with a good dose of reverence and sentimentality" (Mukherjee, 2011, p. 517) while the same was evident in Pakistan's history writing project as was noted by Qasmi (2019). Each country has its own pre and post-independence heroes and martyrs and wars between these two neighbors made the states choose and present their heroes and villains to pupils in textbooks. The Pakistani history textbooks presented Muslims and Islam as the true successor of Indus valley civilization and Buddhists rulers while the Indian textbooks presented all coming from the Central Asian and Chinese side as enemies, invaders and intruders because these descriptions fitted well in the nationalistic historical narrative of both India and Pakistan.

\section{Recommendations}

It is important that the next textbook revision exercise should make textbooks an authentic and accurate account of historical events and personalities, inclusive of their achievements, struggles, and failures. The history textbooks revision exercise should be guided by historians who founded their historical study in the inclusive, humane, and expansive canvass of historical studies and evaluation of different past events with an objective approach. The historians and history textbooks 
writers should ensure that all dots (historical facts and events) are connected, presenting a complete picture to pupils focusing only on information and not on imagined history. The mythicized historical narrative and history was written to indoctrinate young minds to a certain ideology (making the core of identity) and to construct their concepts of ' $u s^{\prime}$ and 'them.' The Indian subcontinent and its history is to be viewed and constructed as the one that had the "ability to accommodate, if not assimilate, an immense diversity within a very broadly and loosely defined framework of unity which has given Indian cultural tradition durability and appearance of unbroken continuity" (Bose \& Jalal, 2017, p. 22).

This study also suggests that the state authorities, bureaucracy, military and civil leadership revise the education and curriculum policy and make it reflective of an inclusive Pakistan, a place where minorities (ethnic, linguistic and religious) are given much-needed acknowledgment and space in Pakistan's historical narrative. The curriculum policy should ensure the historical narrative of Pakistan (pre and post-partition) is rewritten to make it inclusive and reflective of history of the people of Pakistan. The pre-partition historical narrative should inform pupils (read Muslims) about the leaders from minorities who worked along with the leadership of the All India Muslim League and supported them to make Pakistan a reality. The post-partition Pakistan's historical narrative needs to recognize the contribution of minorities in Pakistan's social, cultural, political and economic development.

\section{Notes}

1 Known as Quaid-e-Azam, a title bestowed upon him by the state and people of Pakistan. Its English translation is the greatest leader.

2 Jizya or jizyah is a per capita yearly taxation historically levied in the form of financial charge on permanent non-Muslim subjects of a state governed by Islamic ruler. In return for payment of the jizyah, non-Muslim populations, specifically Jews and Christians were granted protection of life and property and the right to practice their religion. Under this policy they were called dhimmīs (protected people).

\section{References}

Ahmad, I.(2008). The anatomy of an Islamic model: Citizenship education in Pakistan. In D.L. Grossman, O.L. Wing and K.J. Kennedy (Eds.) Citizenship Curriculum in Asia and the Pacific: Singapore: Springer Singapore, pp. 97-109

Ahmed, Z. S.(2017). National identity formation in Pakistan: Analysis of the anti-secular narrative. Journal of Citizenship and Globalisation Studies, 1(1), pp. 63-73.

Ali, D.(2012). Indian historical writing c. 600 to c. 1400. In S. Foot and C.F. Robinson (Eds.) The Oxford History of Historical: 400-1400 (Vol. 2). New York: Oxford University Press, pp. 80-101.

Ali, S. S., \& Rehman, J.(2001). Indigenous Peoples and Ethnic Minorities of Pakistan: Constitutional and legal perspectives. Richmond, Surray: Curzon.

Al-Sahli, H. A.(2013). Turks in India: Their presence and contributions to Islam and civilsation: An historical and analytical study. West East Journal of Social Sciences, 2(2), pp. 12-23.

Amstutz, A.(2019). A Pakistani homeland for Buddhism: Displaying a national history for Pakistan beyond Islam, 1950-1969. South Asia: Journal of South Asian Studies, 42(2), pp. 237-255.

Avari, B.(2007). India, the Ancient Past: A history of the Indian sub-continent from c. 7000 bc to ad 1200. New York: Routledge.

Avari, B.(2013). Islamic civilization in South Asia: A history of Muslim power and presence in the Indian subcontinent. New York: Routledge.

Aziz, K. K.(1993). The Murder of History: A critique of history textbooks used in Pakistan. Lahore: Vanguard Books.

Bajwa, S.(2009). The Genealogy of Pakistan's Nationalist Historiography: An analysis of historiography in the context of the emergent Muslim nationalist discourse, 1857-1947. Unpublished Master's thesis, University of Heidelberg, USA.

Berger, S., \& Lorenz, C.(2008). The Contested Nation: Ethnicity, class, religion and gender in national histories. New York: Palgrave-Macmillan. 
Berggren, D. J.(2009). More than the Ummah: Religious and national identity in the Muslim world. American Journal of Islamic Social Sciences, 24(2), pp. 71-92.

Biontino, J.(2018). History wars' and reconciliation in Japan and Korea: The roles of historians, artists and activists. Contemporary Japan, 30(1), pp. 138-141.

Bose, S., \& Jalal, A.(2017). Modern South Asia: History, culture, political economy. New York: Routledge.

Bruner, J. S.(2002). Making stories: Law, literature, life (1st ed.). Cambridge, MA: Harvard University Press.

Chughtai, M.(2015). What Produces a History Textbook? Unpublished Doctoral dissertation, Harvard University, USA.

Dalrymple, W.(2005). India: The war over history. The New York Review of Books, 52(6), pp. 62-65.

Durrani, N.(2013). Pakistan: curriculum and construction of national identity. In M.E.R. Ahmed (Ed.) Education in West Central Asia. London: Bloomsbury Academic, pp. 221-239.

Durrani, N., \& Dunne, M.(2010). Curriculum and national identity: Exploring the links between religion and nation in Pakistan. Journal of Curriculum Studies, 42(2), pp. 215-240.

Durrani, N., Dunne, M., Fincham, K., \& Crossouard, B.(2017). Pakistan: Converging imaginaries in an Islamic state. In M. Dunne, N. Durrani , K. Fincham, and B. Crossouard (Eds.) Troubling Muslim Youth Identities: Nation, Religion, Gender. London: Palgrave Macmillan, pp. 77-125.

Duus, P.(2017). Introduction: History wars in postwar East Asia, 1945-2014. In M. Lewis (Ed.) History Wars' and Reconciliation in Japan and Korea. New York: Palgrave Macmillan, pp. 1-16

Emerson, A., \& Levi, T. K.(2020). Textbooks, gender and conflict in South Asia: Building the nation. In P. M. Sarangapani and P. Rekha (Eds.) Handbook of Education Systems in South Asia. Singapore: Springer Singapore, pp. 1-28.

Fazila-Yacoobali, V.(1999). A rite of passage: The partition of history and the dawn of Pakistan. Interventions: International Journal of Postcolonial Studies, 1(2), pp. 183-200.

Giunchi, E.(2007). Rewriting the past: Political imperatives and curricular reform in Pakistan. Internationale Schulbuchforschung, 29(4), pp. 375-388.

Gonzalez, L. E., Brown, M. S., \& Slate, J. R.(2008). Teachers who left the teaching profession: A qualitative understanding. Qualitative Report, 13(1), pp. 1-11.

Government of Pakistan (GoP).(1947). Address of the founder of Pakistan Quaid-e-Azam Muhammad Ali Jinnah on 11th August, 1947 to 1st constituent asssembly. Karachi: GoP.

GoP.(2009). National Education Policy 2009. Islamabad: GoP.

Habib, I., Jaiswal, S., \& Aditya, M.(2003). History in the New NCERT Textbooks: A report and index of errors. Calcutta: Indian History Congress.

Hoodbhoy, P. A., \& Nayyar, A. H.(1985). Rewriting the history of Pakistan. In A. Khan (Ed.) Islam, Politics and the State. London: Zed Press, pp. 164-177.

Jaffrelot, C.(2002). Pakistan: Nationalism without a nation. London: Zed Books.

Joshi, S.(2010). Contesting histories and nationalist geographies: a comparison of school textbooks in India and Pakistan. South Asian History and Culture, 1(3), pp. 357-377.

Kalin, M., \& Siddiqui, N.(2017). National identity, religious tolerance, and group conflict: Insights from a survey experiment in Pakistan. Conflict Management and Peace Science, 37(1), pp. 1-25.

Khyber Pakhtunkhwa Textbook Board (KPKTB).(2017a). History for Class 6. Peshawar: Khyber Pakhtunkhwa Textbook Board.

KPKTB.(2017b). History for Class 7. Peshawar: Khyber Pakhtunkhwa Textbook Board.

KPKTB.(2017c). History for Class 8. Peshawar: Khyber Pakhtunkhwa Textbook Board.

Klerides, L. E.(2008). The Discursive (Re) construction of National Identity in Cyprus and England with Special Reference to History Textbooks: A comparative study. Unpublished Doctoral dissertation, University of London, UK.

Kurin, R.(1985). Islamization in Pakistan: A view from the countryside. Asian Survey, 25(8), pp. 852862.

Kurth, J.(2007). Religion and national identity in America and Europe. Society, 44(6), pp. 120-125. 
Lall, M.(2008). Educate to hate: The use of education in the creation of antagonistic national identities in India and Pakistan. Compare: A Journal of Comparative and International Education, 38(1), pp. 103-119.

Lall, M.(2012). Citizenship in Pakistan: State, nation and contemporary faultlines. Contemporary politics, 18(1), pp. 71-86.

Lane-Poole, S.(1906) Mediaeval India from the Mohammedan conquest to the reign of Akbar the Great. In A. V. W. Jackson (Ed.) History of India. London: The Grolier Society.

Majumdar, R. C.(1951). The History and Culture of the Indian people: The Vedic age. Mumbai: Bharatiya Vidya Bhavan.

Martin, D. C.(1995). The choices of identity. Social Identities, 1(1), pp. 5-20.

Mohammad-Arif, A. (2007). Textbooks, nationalism and history writing in India and Pakistan. In V. Bénéï (Ed.) Manufacturing Citizenship: Education and nationalism in Europe, South Asia and China. New York: Routledge, pp. 155-181.

Muhammad, Y.(2015). Pakistani National Identity, Cultural Diversity, and Global Perspectives: A policy trajectory study of the national. Unpublished Doctoral dissertation, University of Tasmania, Australia.

Muhammad, Y., \& Brett, P.(2017). Some challenges in teaching citizenship in an Islamic context: Pakistan Studies teachers' perspectives and practices in relation to teaching about identity. Citizenship Teaching \& Learning, 12(3), pp. 279-298.

Mukherjee, S.(2011). Indian historical writing since 1947. In A. Schneider and D. Woolf (Eds.) The Oxford History of Historical Writing: Historical writing since 1945 (Vol. 5). New York: Oxford University Press, pp. 515-538.

Myhill, J. (2006). Language, Religion and National Identity in Europe and the Middle East: A historical study (Vol. 21). Amsterdam: John Benjamins Publishing.

Naseem, A. M.(2005). Peace in times of globalization: De-(constructing) militaristic identities in language and social studies textbooks in South Asia: the case of Pakistan. In E. Bruillard, B. Aamotsbakken, S.V. Knudsen \& M. Horsley (Eds.). Caught In The Web Or Lost In The Textbook?. IARTEM: Kongsberg, Norway, pp. 179-186.

Naseem, M. A., Ghosh, R., McGill, J., \& Mcdonald, W. C.(2010). Construction of the 'other'in history textbooks in India and Pakistan. In G. Pampanini, F. Adly, and D. B. Napier (Eds.) Interculturalism, Society and Education: Amsterdam: Brill Sense, pp. 37-44.

Neuendorf, K. A. (2017). The Content Analysis Guidebook (2nd ed.). Thousand Oaks, CA: Sage.

Ozkirimli, U.(2000). Theories of Nationalism: A critical introduction. New York: Palgrave MacMillan.

Ozkirimli, U.(2005). Contemporary Debates on Nationalism: A critical engagement New York: Palgrave Macmillan.

Punjab Curriculum and Textbook Board (PCTB).(2017a). History Class 6. Lahore: Punjab Curriculum and Textbook Board.

PCTB.(2017b). History Class 7. Lahore: Punjab Curriculum and Textbook Board.

PCTB.(2017c). History for Class 8. Lahore: Punjab Curriculum and Textbook Board.

Propp, V.(1968). Morphology of the Folktale (L. Scott, Trans. 2nd ed.). Austin, TX: University of Texas Press.

Qasmi, A. U.(2019). A master narrative for the history of Pakistan: Tracing the origins of an ideological agenda. Modern Asian Studies, 53(4), pp. 1066-1105.

Rahman, M., Hamzah, M. I. M., Meerah, T., \& Rahman, M.(2010). Historical development of secondary education in Bangladesh: Colonial period to 21st century. International Education Studies, 3(1), pp. 114-125.

Rosser, Y. C.(2003). Curriculum as destiny: Forging national identity in India, Pakistan, and Bangladesh. Unpublished Doctoral dissertation, University of Texas at Austin, USA.

Saigol, R.(2003). History, social studies and civics and the creation of enemies. In A. Zaidi, S. (Ed.) Social Science in Pakistan in the 1990s. Islamabad: Council of Social Sciences, pp. 159-200. 
Saigol, R.(2005). Enemies within and enemies without: The besieged self in Pakistani textbooks. Futures, 37(9), pp. 1005-1035.

Sarkar, J.(2009). A Short History of Aurangzib. Hyderabad, India: Orient Blackswan Private Limited.

Schneider, C.(2008). The Japanese history textbook controversy in East Asian perspective. The ANNALS of the American Academy, 617, pp. 107-122.

Sen, A.(2012). The Argumentative Indian: Writings on Indian history, culture and identity. New Delhi: Penguin Books India.

Shafqat, S.(2009). Pakistani national identity: Muslim, multilingual and multicultural? Quarterly Research \& News. 5 \& 6, pp. 2-5.

Shah, S. J., \& Ishaque, W.(2017). Challenges of national integration in Pakistan and strategic response. ISSRA PAPERS, 9(2), pp. 35-48.

Sharma, G.(2020). Conceptions of school curriculum in South Asia: A study of India, Pakistan, and Bangladesh. In P.M. Sarangapani and P. Rekha (Eds.) Handbook of Education Systems in South Asia. Singapore: Springer Singapore, pp. 1-26.

Sindh Textbook Board (STB).(2017a). Social Studies for Class 6. Jamshoro, Sindh: Sindh Textbook Board. STB.(2017b). Social studies for Class 7. Jamshoro, Sindh: Sindh Textbook Board.

STB.(2017c). Social studies for Class 8. Jamshoro, Sindh: Sindh Textbook Board.

Thapar, R.(2011). Historical traditions in Early India c. 1000 BC to c. 600 AD. In A. Feldherr and G. Hardy (Eds.) The Oxford History of Historical Writing: Beginnings to AD 600 (Vol. 1). New York: Oxford University Press, pp. 553-576.

Thijs, K.(2008). The metaphor of the master: 'Narrative hierarchy' in national historical cultures of Europe. In S. Berger and C. Lorenz (Eds.) The Contested Nation: Ethnicity, class, religion and gender in national histories. London: Palgrave Macmillan.

van Wiele, J.(2008). Ex oriente lux? The representation of Asiatic religions and cultures in Catholic education from 1870 until 1950. Missionalia: Southern African Journal of Mission Studies, 36(1), pp. 60-85.

Wertsch, J. V.(2008). The Narrative organization of collective memory. Ethos, 36(1), pp. 120-135.

Witzel, M.(1990). On Indian historical writing: The role of the Vamçâvalîs. Minamiajiakenkyu, 2, pp. 1-57.

Wodak, R., De Cillia, R., Reisigl, M., \& Liebhart, K.(2009). The Discursive Construction of National Identity (A. Hirsch, R. Mitten, and J. W. Unger, Trans. 2nd ed.). Edinburgh Edinburgh University Press.

Yaqian, W.(2011). Defining the Pakistani Nation in History Education: An examination of Pakistan Studies textbooks. Unpublished Master's dissertation, National University of Singapore, Singapore.

Zaidi, S. M. A.(2011). Polarisation of social studies textbooks in Pakistan. Curriculum Journal, 22(1), pp. 43-59.

Zakaria, A.(2018). By Rewriting History, India, Pakistan, Bangladesh are Threatening the Very Identity of Their People: India is going down a path its neighbours have walked decades ago. Available at: https://scroll.in/article/print/871352 [Accessed 2 March 2020]. 